ORIGINAL RESEARCH PAPER

\title{
OPTIMIZATION OF THE ANTIOXIANT PEPTIDES PRODUCTION FROM GOAT MILK CASEIN HYDROLYZED BY ALCALASE AND PAPAIN USING RESPONS SURFACE METHODOLOGY
}

\author{
GUOWEI SHU ${ }^{1 *}$, SHA MEI ${ }^{1}$, LI CHEN $^{2}$, BINYUN CAO $^{3}$, QIAN ZHANG $^{1}$, HE CHEN $^{1}$ \\ XIUXIU CUI ${ }^{4}$

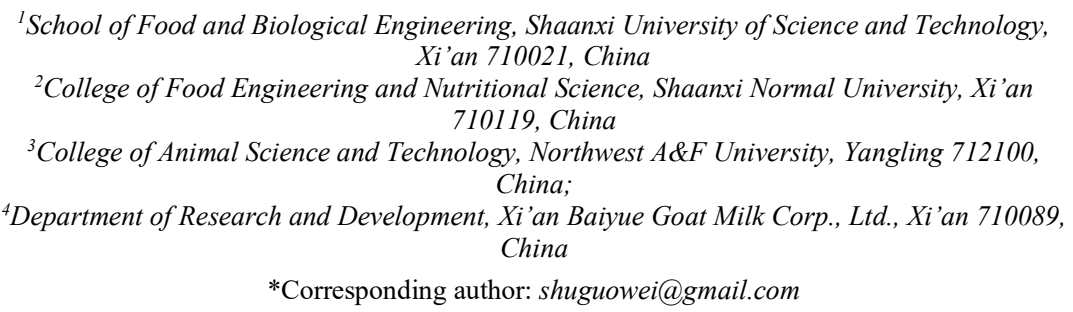

Received on 12 November 2018

Revised on 25 January 2019

\begin{abstract}
Antioxidant peptides are widely used in many fields due to their biological activities such as anti-cancer, anti-induction and anti-aging. However, little information is available concerning the peptides production by enzymatic hydrolysis of casein from goat milk. In this study, response surface methodology (RSM) was applied to optimize the conditions of the hydrolysis of goat milk casein by proteases (alcalase in combination with papain) to increase the antioxidant activity of the peptides. The results showed that the optimal hydrolysis conditions were as follows: temperature of $61^{\circ} \mathrm{C}$, enzyme/substrate ratio (E/S) of $5.6 \%$, and protease ratio (papain: alcalase) of 1.8:1. Under the optimal conditions, the 1,1-diphenyl-2-picrylhydrazyl (DPPH) radical scavenging activity significantly increased (1.17 folds compared to un-optimized conditions). Furthermore, $\mathrm{Fe}^{2+}$ chelating ability and superoxide radical scavenging activity increased 1.02 folds and 1.14 folds, respectively. The antioxidant activity was significantly improved after optimization and provided a basis for the study of the antioxidant effects of hydrolysed goat milk casein.
\end{abstract}

Keywords: goat milk casein, alcalase, papain, antioxidant activity, response surface methodology

\section{Introduction}

Reactive oxygen species (ROS) and free radicals are natural by-products of normal human metabolism (Ray et al., 2012). Under normal circumstances, the production and elimination of free radicals in the body is in a dynamic equilibrium, which will

https//doi.org/10.35219/foodtechnology.2019.1.02 
not cause damage to the body (Jomova \& Valko, 2011; Galadari et al., 2017). However, when the production of free radicals and reactive oxygen groups is excessive, the normal redox balance of the body is destroyed, and the defense system of ROS in the body can not completely resist the damage of free radicals and ROS. The lipids, proteins and DNA are oxidized causing damages to the body that can lead to various diseases (Ko et al., 2012).

Studies showed that ingesting foods full of antioxidants is a rational way to scavenge free radicals and reduce oxidation damage for humans (Boboev et al., 2012; Freitas et al., 2013). Chemically synthesized antioxidants can cause negative effects and the applications of that are limited. The natural antioxidants gained more and more attention in recent years not only because they can reduce the rate of oxidation and the generation of free radicals, but also because they can prevent the occurrence of lipid oxidation reactions (Sarmadi \& Ismail, 2010). Antioxidant peptides obtained from plant and animal derived proteins by enzymatic and fermentation methods have many advantages, such as wide range of sources, nontoxic effects and stable antioxidant properties ( $\mathrm{Yu}$ et al., 2017). The antioxidant peptides produced through enzymatic hydrolysis of food proteins are not only more easily digested and absorbed by the human body than the protein itself, but also promotes the absorption of other nutrients such as calcium and iron (Najafian \& Babji, 2014). Nagai et al. (2006) found that once royal jelly was hydrolysed using enzyme, the hydrolysates possessed much higher antioxidant activity and scavenging activity against active oxygen species. Adeola et al. (2014) reported the oxygen radical absorbance capacity of the canola proteins hydrolysed by alcalase, chymotrypsin and pepsin were found to be higher than that of glutathione, and that it could be used as bioactive ingredients in the formulation of functional foods against oxidation stress.

Goat milk was called "white blood", because it is rich in proteins, lipids, amino acids, minerals and vitamins. Goat milk also has cholesterol lowering, antioxidative, anti-inflammatory, repairing intestinal tract, and reducing lactose intolerance properties, which ensure the goat milk with two functions - nutrition and health care (Chilliard et al., 2010; Li et al., 2013). Compared to cow milk goat milk has higher amounts of $\beta$-casein and $\kappa$-casein and it has little or no allergen as1-casein that causes the allergic reactions. The whey proteins content of goat milk is higher, easier to digest and absorb than those of cow milk. The ratio between casein and whey proteins of goat milk is closer to human milk and it is recommended for neonates when the human milk is missing (Kapadiya et al., 2016). However, studies regarding goat milk casein-derived hydrolysates and their active peptides were rarely reported and in addition, the researches regarding goat milk lags behind cow milk.

In our previous studies, alcalase proved to be the best proteinase for hydrolyzing goat milk casein in order to produce antioxidant peptides compared to flavourzyme, papain, proteinase K and trypsin (Shu et al., 2015). Furthermore, the influence of various factors (hydrolysis temperature, $\mathrm{pH}$, substrate concentration, enzyme/substrate ratio (E/S), the ratio of protease and time) on the preparation of 
the antioxidant peptides by alcalase combined with papain hydrolysis of goat milk casein were performed by single factors experiment and Plackett-Burman design. According to the results, temperature, $\mathrm{E} / \mathrm{S}$ ratio and the protease ratio were selected as the most important factors, which had significant influences on the antioxidant activity of the peptides (Shu \& Mei, 2018). In this paper, the hydrolysis conditions for preparing antioxidant peptides through protease hydrolysis of goat milk casein to obtain high antioxidant activity were optimized by Box-Behnken design and response surface methodology.

\section{Materials and methods}

\section{Materials}

Goat milk powder was supplied by Xi'an Baiyue Dairy Co., Ltd, (Shaanxi, China). Alcalase, papain, DPPH and 3-(2-pyridyl)-5,6-bis (4-phenylsulphonic acid)-1,2,4triazine (Ferrozine) were purchased from Sigma-Aldrich, (St. Louis, Mo, USA). All other reagents used in this study were of analytical grade.

\section{Preparation of goat milk casein}

The goat milk powder and distilled water were mixed at a ratio of $1: 8(\mathrm{w} / \mathrm{v})$ then the fat was removed by centrifugation at $6500 \mathrm{rpm}$ for $15 \mathrm{~min}$ in order to obtain skimmed goat milk. Further, the skimmed milk was heated up to $45^{\circ} \mathrm{C}$, and the $\mathrm{pH}$ was adjusted to 4.6 units with $\mathrm{HCl} 1 \mathrm{M}$ to precipitate the goat milk casein. The goat milk casein was separated by centrifugation at $6500 \mathrm{rpm}$ for $15 \mathrm{~min}$. The precipitate was collected and freeze-dried using the vacuum freeze dryer (Beijing Boyikang Experimental Instrument Co., Ltd, Beijing, China) for further analysis.

\section{Preparation of enzymatic hydrolysis}

The freeze-dried goat milk casein was mixed with distilled water at a ratio of 2:100 $(\mathrm{w} / \mathrm{v})$. A certain amount $(5.5 \%, 5.6 \%, 5.7 \%)$ of the enzyme complex was added to the casein solution. Next, the solution was adjusted to the optimum value of the temperature $\left(60^{\circ} \mathrm{C}, 61^{\circ} \mathrm{C}, 62^{\circ} \mathrm{C}\right)$ and $\mathrm{pH}$ of 7.5 for the enzyme complex. During the reaction, the hydrolysis $\mathrm{pH}$ was maintained at the specified value by adding $0.1 \mathrm{M}$ $\mathrm{NaOH}$ continually. The hydrolysis was completed by heating up the samples to $95^{\circ} \mathrm{C}$ for $15 \mathrm{~min}$ to inactivate the enzymes. Then, the $\mathrm{pH}$ was adjusted to 3.4 , and the hydrolysates were centrifuged at $6000 \mathrm{rpm}$ for $15 \mathrm{~min}$ to collect the supernatant followed by the adjustment of the $\mathrm{pH}$ up to 8.0 , centrifugation at $6000 \mathrm{rpm}$ for 15 min and collection of the supernatant.

\section{Determination of the antioxidant activity}

\section{DPPH radicals scavenging activity}

The DPPH radicals scavenging activity of the peptides was measured by the method of Wu et al. (2003). Two $\mathrm{mL}$ of the enzymatic hydrolysate was placed in a test tube and mixed with $2 \mathrm{~mL}$ of $0.1 \mathrm{mM}$ DPPH (in 95\% ethanol). Then, the samples were homogenized and dark incubated for $30 \mathrm{~min}$ at room temperature. The absorbance was measured at $517 \mathrm{~nm}$. A mixture obtained from $2 \mathrm{~mL}$ sample and $2 \mathrm{~mL}$ of $95 \%$ ethanol without DPPH solution was used as blank, and $2 \mathrm{~mL}$ 
DPPH radical solution in $2 \mathrm{~mL}$ of $95 \%$ ethanol was used as control. The DPPH radical scavenging activity was calculated according to equation 1 :

$$
\text { DPPH radical scavenging activity }(\%)=100-100 \times \frac{\left(A_{1}-A_{2}\right)}{A_{0}}
$$

where $A_{1}$ represents the absorbance of the experiment group, $A_{0}$ represents the absorbance of the control, and $\mathrm{A}_{2}$ represents the absorbance of the blank.

\section{Metal chelation ability}

The chelating of $\mathrm{Fe}^{2+}$ for enzymatic hydrolysates was estimated by the method of Decker \& Welch (1990). A quantity of $1 \mathrm{~mL}$ of enzymatic hydrolysate and $3.7 \mathrm{~mL}$ of distilled water were mixed in a test tube. Then, $0.1 \mathrm{~mL}$ of $2 \mathrm{mM} \mathrm{FeCl}_{2}$ solution and $0.2 \mathrm{~mL}$ of $5 \mathrm{mM}$ ferrozine solution were added. The reaction was allowed to take place for $20 \mathrm{~min}$, at room temperature. After that, the absorbance of mixture was measured at $562 \mathrm{~nm}$. The control was obtained by adding distilled water instead of enzymatic hydrolysate. The chelating activity was calculated according to equation 2:

$$
\text { Chelating ability }(\%)=100-\left(100 \times \mathrm{A}_{1} / \mathrm{A}_{2}\right)
$$

where $A_{1}$ was the absorbance of the sample, $A_{2}$ was the absorbance of the control.

\section{Superoxide radical scavenging activity}

The method of measuring superoxide radical scavenging activity was according to the described by Marklund \& Marklund (1974) with some modifications. $5.7 \mathrm{~mL}$ of $50 \mathrm{mM} / \mathrm{L}$ Tris-HCl-EDTA buffer $(\mathrm{pH} 8.2,1 \mathrm{mM} / \mathrm{L}$ of EDTA) and $0.2 \mathrm{~mL}$ of enzymatic hydrolysate were added into a test tube. Then, $0.1 \mathrm{~mL}$ of $5 \mathrm{mM} / \mathrm{L}$ pyrogallol was added and the optical density was measured at $325 \mathrm{~nm}$. A control was used by adding distilled water instead of enzymatic hydrolysate. The data was recorded every $30 \mathrm{~s}$ and the reaction was completed after $5 \mathrm{~min}$. The superoxide radical scavenging activity was calculated based on the following formula:

$$
\text { Superoxide radical scavenging activity }(\%)=\left[1-\left(\mathrm{A}_{1} / \mathrm{min}\right) /\left(A_{2} / \mathrm{min}\right)\right] \times 100
$$

where $A_{1} /$ min is the absorbance per minute of the sample (sample and buffer); $\mathrm{A}_{2} / \mathrm{min}$ is the absorbance per minute of the control (buffer and distilled water).

\section{Optimization of fermentation conditions by RSM}

Response surface methodology was used for further optimization studies by determining the response value and analyzing the various effects. Box-Behnken design of three variables and three levels of variation was built according to determined three main factors, temperature (A), E/S (B) and the protease ratio (C), which were used to find the optimal conditions of the hydrolysing goat milk casein by fitting a polynomial model with RSM. The experimental design of three levels of variables was shown in Table 1 . 
Table 1. The experimental factors and coded levels for obtaining peptides by protease hydrolysis

\begin{tabular}{ccccc}
\hline \multirow{2}{*}{ Variables } & Factors & $(-1)$ & 0 & $(+1)$ \\
\hline $\mathrm{A}$ & Temperature $\left({ }^{\circ} \mathrm{C}\right)$ & 60 & 61 & 62 \\
$\mathrm{~B}$ & $\mathrm{E} / \mathrm{S}(\%)$ & 5.5 & 5.6 & 5.7 \\
$\mathrm{C}$ & Proteases ratio $(\mathrm{mg} / \mu \mathrm{L})^{*}$ & $10: 5$ & $11: 6$ & $12: 7$ \\
\hline
\end{tabular}

* protease ratio refers to papain: alcalase

\section{Model validation}

The hydrolysis conditions were applied in further experiments based on the results of RSM and the experimental values were compared with predictive value to verify the effectiveness of the model. Three sets of experiments were made and the results were expressed as mean deviation.

\section{Statistical Analysis of the Data}

Design Expert software version 8.0.6 (Stat-Ease Inc., MN, USA) was used to design the experiment and analyze the data.

\section{Results and discussion}

\section{Box-Behnken experimental design}

Box-Behnken design was used to determine the optimal combination of the three significant factors, such as: temperature, enzyme/substrate ratio and protease ratio in order to prepare the antioxidant peptide. The experimental design and results are showed in Table 2. The responses analyzed were: DPPH radical scavenging activity (R1), $\mathrm{Fe}^{2+}$ chelation ability (R2) and superoxide radical scavenging activity (R3).

\section{Regression analysis}

The quadratic regression model was established based on the data provided by the Box-Behnken design. The multivariate regression equations correlating the responses depending with the independent variables were listed according to equations 4,5 and 6 :

$$
\begin{aligned}
& R 1=74.07-0.25 \mathrm{~A}-0.44 \mathrm{~B}+0.88 \mathrm{C}-1.17 \mathrm{AB}+0.12 \mathrm{AC}-0.98 \mathrm{BC}-7.48 \mathrm{~A}^{2}-0.22 \mathrm{~B}^{2}-5.75 \mathrm{C}^{2} \\
& R 2=93.89-0.27 \mathrm{~A}-0.47 \mathrm{~B}-0.24 \mathrm{C}+0.29 \mathrm{AB}+0.38 \mathrm{AC}+0.79 \mathrm{BC}-3.19 \mathrm{~A}^{2}-3.38 \mathrm{~B}^{2}+0.26 \mathrm{C}^{2} \\
& R 3=51.08+1.14 \mathrm{~A}-0.021 \mathrm{~B}-0.23 \mathrm{C}-1.42 \mathrm{AB}-0.33 \mathrm{AC}+1.5 \mathrm{BC}-2.48 \mathrm{~A}^{2-4} .27 \mathrm{~B}^{2}-1.73 \mathrm{C}^{2}
\end{aligned}
$$

where, A, B and C are coded values of the independent variables for temperature, $\mathrm{E} / \mathrm{S}$ ratio and the protease ratio, $\mathrm{R} 1, \mathrm{R} 2$ and $\mathrm{R} 3$ represents the corresponding expected values including the DPPH radical scavenging activity, the $\mathrm{Fe}^{2+}$ chelating ability and the superoxide radical scavenging activity, respectively. 
Table 2. The Box-Behnken design and the experimental data for the responses of production peptide in the enzymatic hydrolysis

\begin{tabular}{|c|c|c|c|c|c|c|}
\hline \multirow[b]{2}{*}{ Runs } & \multicolumn{3}{|c|}{ Variables } & \multirow{2}{*}{$\begin{array}{c}\text { DPPH } \\
\text { radical } \\
\text { scavenging } \\
\text { activity, } \% \text {, } \\
\text { R1 }\end{array}$} & \multirow{2}{*}{$\begin{array}{c}\mathrm{Fe}^{2+} \\
\text { chelation } \\
\text { ability, \%, } \\
\text { R2 }\end{array}$} & \multirow{2}{*}{$\begin{array}{c}\text { Superoxide } \\
\text { radical } \\
\text { scavenging } \\
\text { activity, }(\% \text {, } \\
\text { R3 }\end{array}$} \\
\hline & $\begin{array}{c}\text { Temperature },{ }^{\circ} \mathrm{C}, \\
\text { A }\end{array}$ & $\begin{array}{c}\mathrm{E} / \mathrm{S}, \% \\
\mathrm{~B}\end{array}$ & $\begin{array}{l}\text { Protease } \\
\text { ratio } \\
(\mathrm{mg} / \mathrm{ml}, \\
\mathrm{C})\end{array}$ & & & \\
\hline 1 & $-1(60)$ & $1(5.7)$ & $0(11: 6)$ & 66.76 & 86.28 & 45.25 \\
\hline 2 & -1 & $-1(5.5)$ & 0 & 66.81 & 88.93 & 42.25 \\
\hline 3 & $1(62)$ & $0(5.6)$ & $1(10: 5)$ & 71.25 & 87.35 & 48.75 \\
\hline 4 & $0(61)$ & 0 & 0 & 74.76 & 92.21 & 51.75 \\
\hline 5 & 0 & 1 & 1 & 66.96 & 90.23 & 44.08 \\
\hline 6 & -1 & 0 & $-1(12: 7)$ & 70.12 & 87.26 & 45.67 \\
\hline 7 & 1 & -1 & 0 & 68.81 & 87.79 & 46.25 \\
\hline 8 & 0 & 0 & 0 & 74.97 & 94.83 & 51.33 \\
\hline 9 & 1 & 0 & -1 & 71.24 & 88.65 & 48.42 \\
\hline 10 & 0 & 1 & -1 & 69.81 & 91.85 & 45.83 \\
\hline 11 & 1 & 1 & 0 & 69.52 & 86.31 & 43.58 \\
\hline 12 & 0 & 0 & 0 & 74.97 & 94.83 & 51.33 \\
\hline 13 & -1 & 0 & 1 & 66.6 & 89.15 & 44.67 \\
\hline 14 & 0 & -1 & 1 & 70.35 & 91.28 & 47.33 \\
\hline 15 & 0 & -1 & -1 & 60.11 & 90.11 & 43.08 \\
\hline
\end{tabular}

\section{Variance analysis of DPPH free radical scavenging rate regression equation}

The Analysis of variance (ANOVA) was applied to evaluate the significant coefficients in the models to determine the effect of different variables. The lower $p$-value indicates the more obvious effect of variable. R-squared value represents the fitness of the predicted value and the model.

The results of ANOVA test in regression equation were shown in Table 3. The $p$ value of the regression equation model $(p=0.0028<0.01)$ was statistically significant and the $\mathrm{F}$ value was 5.62. The $p$-value of the lack of fit $(p=0.1371>0.1)$ was insignificant showing that the regression analysis was valid, which suggested that the regression model could be used to fit the effect of three factors on DPPH radical scavenging activity. The coefficient of determination $\left(\mathrm{R}^{2}=0.9101\right)$ suggested that more than $91.01 \%$ of the total variation in the response could be explained by the model. The adjusted coefficient of determination $\left(\mathrm{R}^{2}{ }_{\mathrm{Adj}}=74.83 \%\right)$ was close to the $\mathrm{R}^{2}$ value, confirming that the measured and predicted values had a high fitting precision proving the feasibility of the experimental method. The quadratic main effects of temperature, $\mathrm{E} / \mathrm{S}$ and protease ratio were significant $\left(p_{\mathrm{A}}{ }^{2}\right.$ $<0.01, p_{\mathrm{B}}^{2}<0.001, p_{\mathrm{C}}^{2}<0.01$ ), which suggested that there wasn't a simple linear correlation between the variables and DPPH radical scavenging activity. 
Table 3. The ANOVA of Box-Behnken of DPPH radical scavenging activity in the enzymatic hydrolysates

\begin{tabular}{ccccccc}
\hline Source & SS & DF & MS & F & P $>$ F & Significance \\
\hline Model & 211.89 & 9 & 23.54 & 5.62 & 0.0028 & $* *$ \\
A & 13.86 & 1 & 13.86 & 3.31 & 0.0180 & $*$ \\
B & 6.07 & 1 & 6.07 & 1.45 & 0.9513 & \\
C & 1.88 & 1 & 1.88 & 0.45 & 0.5201 & \\
AB & 0.14 & 1 & 0.14 & 0.034 & 0.0291 & $*$ \\
AC & 3.12 & 1 & 3.12 & 0.74 & 0.5090 & \\
BC & 42.84 & 1 & 42.84 & 10.23 & 0.0238 & $*$ \\
$\mathrm{~A}^{2}$ & 18.39 & 1 & 18.39 & 4.39 & 0.0021 & $* *$ \\
$\mathrm{~B}^{2}$ & 100.87 & 1 & 100.87 & 24.10 & 0.0002 & $* * *$ \\
$\mathrm{C}^{2}$ & 42.66 & 1 & 42.66 & 10.19 & 0.0078 & $* *$ \\
Residual & 20.93 & 5 & 4.19 & & & \\
Lack of fit & 18.97 & 3 & 6.32 & 6.45 & 0.1371 & \\
Pure error & 1.96 & 2 & 0.98 & & & \\
Cor Total & 232.82 & 14 & & & & \\
\hline$* * * p<0.001$, extremely significant $* * * p<0.01$, very significant $* p<0.05$, significant. &
\end{tabular}

The contour plots and 3D surface plot of the DPPH radical scavenging activity in model equation are showed in the figure 1 . The contour plots seemed to be elliptical or circular. It implied that $\mathrm{A} \times \mathrm{B}, \mathrm{A} \times \mathrm{C}$ and $\mathrm{B} \times \mathrm{C}$ had mutual interactions for DPPH radical scavenging activity and they were significant $\left(p_{\mathrm{AB}}=0.0291<\right.$ $0.05, p_{\mathrm{AC}}=0.0238<0.05$ ). Therefore, the effect of one factor on DPPH radical scavenging activity was dependent on the level of another one.

\section{Variance analysis of $\mathrm{Fe}^{2+}$ chelation ability regression equation}

According to the results showed in Table 4, the probability value for $\mathrm{Fe}^{2+}$ chelating ability $(\mathrm{p}=0.0215<0.05)$ demonstrated a high significance for the regression model. Instead, the $p$-value of the lack of fit $(p=0.7433>0.1)$ was not significant, which indicated that the regression analysis model was effective and the regression model could be used to fit the effect of three factors on $\mathrm{Fe}^{2+}$ chelating ability. The value of the coefficient of determination $\left(\mathrm{R}^{2}=0.9280\right)$ showed that the quadratic equation could be used to illustrate more than $90.78 \%$ of variations in the response. Besides, the value of adjusted determination coefficient $\left(\mathrm{R}^{2} \mathrm{Adj}=79.85 \%\right)$ expressed that the model had high potential in predicting response. The factors influence on $\mathrm{Fe}^{2+}$ chelating ability was obtained as follow: $B>A>C$, it showed that the $E / S$ had the highest effect on $\mathrm{Fe}^{2+}$ chelating ability, followed by temperature and protease ratio. The p-value of both A2 and B2 were less than 0.05, which showed a significant effect on the $\mathrm{Fe}^{2+}$ chelation ability and had a greater effect on the model. 
(a)

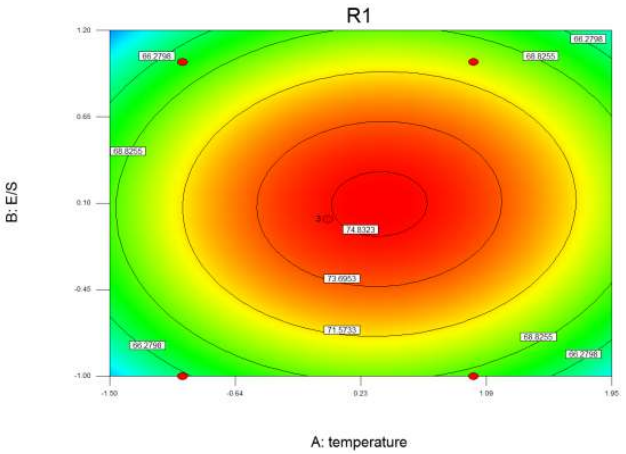

(c)

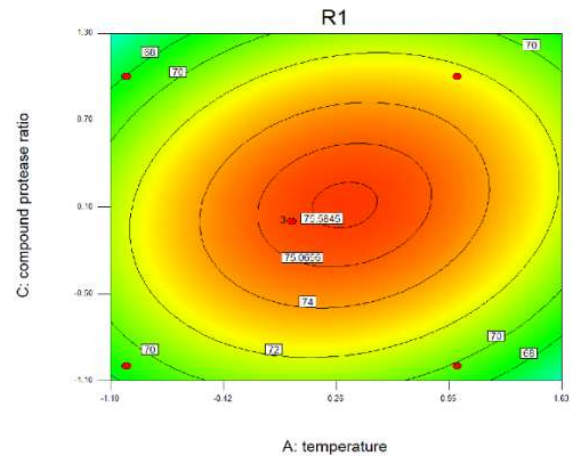

(e)

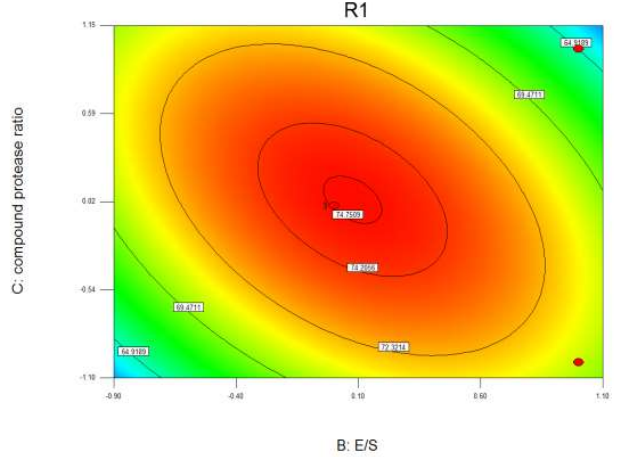

(b)

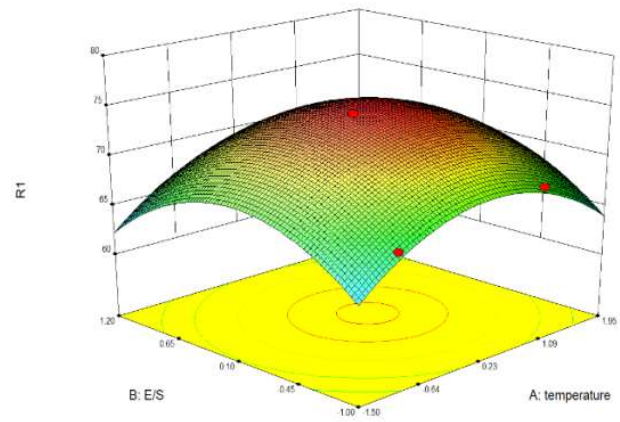

(d)

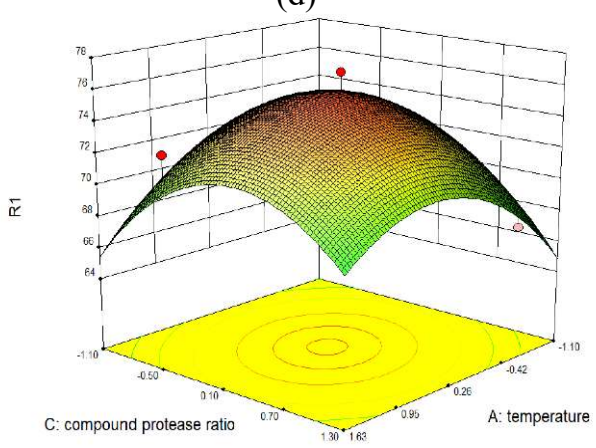

(f)

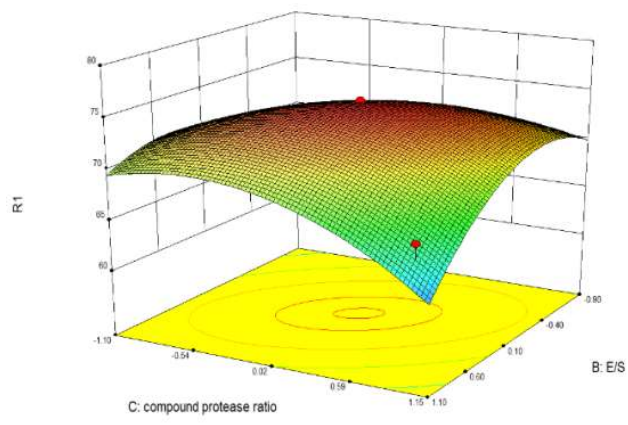

Figure 1. Response surface (right) and contour (left) plots of A (temperature), B (E/S), C (compound protease ratio) and its mutual interaction to R1 (DPPH radical scavenging activity)

According to the contour map and 3D surface map drawn by the model equation in figure 2, the three sets of 3D surface maps were arched with different degrees of curvature, which indicated that the value of $\mathrm{Fe}^{2+}$ chelating ability was increased with the gradual increase of various factors. When a certain value was reached, the value of each factor would continue to increase and the value of $\mathrm{Fe}^{2+}$ chelating 
ability would decrease. From the contour plot it can be seen that $\mathrm{A} \times \mathrm{B}, \mathrm{A} \times \mathrm{C}$ and $\mathrm{B} \times \mathrm{C}$ exhibited weaker elliptical and irregular patterns, showing that the interaction was not significant.

Table 4. The ANOVA of Box-Behnken of $\mathrm{Fe}^{2+}$ chelating ability in the enzymatic hydrolysed

\begin{tabular}{ccccccc}
\hline Source & SS & DF & MS & F & Pr $>$ F & Significance \\
\hline Model & 98.97 & 9 & 11.00 & 7.16 & 0.0215 & $*$ \\
A & 0.29 & 1 & 0.29 & 0.19 & 0.6828 & \\
B & 1.48 & 1 & 1.48 & 0.96 & 0.3714 & \\
C & 0.48 & 1 & 0.48 & 0.29 & 0.9697 & \\
AB & 0.34 & 1 & 0.34 & 0.22 & 0.6567 & \\
AC & 2.54 & 1 & 2.54 & 1.66 & 0.2544 & \\
BC & 1.95 & 1 & 1.95 & 1.27 & 0.3114 & $* * *$ \\
$\mathrm{~A}^{2}$ & 81.46 & 1 & 81.46 & 53.06 & 0.0008 & $*$ \\
$\mathrm{~B}^{2}$ & 13.78 & 1 & 13.78 & 8.98 & 0.0302 & \\
$\mathrm{C}^{2}$ & 4.94 & 1 & 4.94 & 3.22 & 0.1327 & \\
Residual & 7.68 & 5 & 1.54 & & & \\
Lack of fit & 3.10 & 3 & 1.03 & 0.45 & 0.7433 & \\
Pure error & 4.58 & 2 & 2.29 & & & \\
Cor Total & 106.65 & 14 & & & & \\
\hline
\end{tabular}

${ }^{* * *} p<0.001$, extremely significant; ${ }^{*}{ }_{p}<0.01$, very significant; ${ }^{*} p<0.05$, significant.

\section{Variance analysis of superoxide radical scavenging activity regression equation}

As shown in Table 5, the probability value for superoxide radical scavenging activity $(p=0.0028<0.01)$ was statistically significant and the probability value for the lack of fit $(p=0.3595>0.1)$ was insignificant which indicated that the regression analysis was effective. The value of the coefficient of determination $\left(\mathrm{R}^{2}=96.96 \%\right)$ showed that only $3.04 \%$ of the variability in superoxide anion clearance rate could not be explained by the predicted equation of model. Furthermore, the value of adjusted determination coefficient $\left(\mathrm{R}_{\mathrm{Adj}}^{2}=91.48 \%\right)$ was near to the coefficient determination, which demonstrated the experimental results fitted to the model equation. The three factors influence on the superoxide radical scavenging activity was obtained as follows: $\mathrm{A}>\mathrm{C}>\mathrm{B}$, showing that the temperature presented the highest effect on R3, followed by the compound protease ratio and the E/S. The $p$ value of $\mathrm{A}, \mathrm{A}^{2}, \mathrm{~B}^{2}$ and $\mathrm{C}^{2}$ were all less than 0.05 , indicating a significant effect on both the superoxide radical scavenging activity and the model itself.

The contour plots and 3D-surface plots were shown in figure 3 . The contour plots of $\mathrm{A} \times \mathrm{B}$ and $\mathrm{B} \times \mathrm{C}$ were elliptical, implying that $\mathrm{A} \times \mathrm{B}$ and $\mathrm{B} \times \mathrm{C}$ had significant mutual interactions for superoxide radical scavenging activity $\left(p_{\mathrm{AB}}=0.0391<0.05\right.$, $\left.p_{\mathrm{BC}}=0.0323<0.05\right)$. In figure $3(\mathrm{c})$ the circular shape of $\mathrm{A} \times \mathrm{C}$ illustrated a weak 
mutual interaction $\left(p_{\mathrm{AC}}=0.5436>0.05\right)$. The 3D surface map was a convex arch, indicating that there was a maximum value of superoxide radical scavenging activity under the interaction of these three factors.

(a)

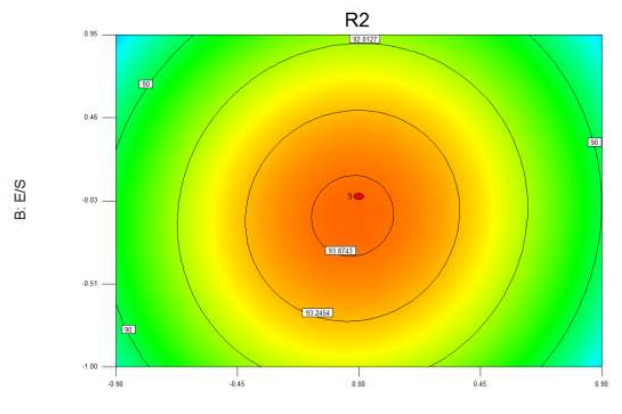

(c)

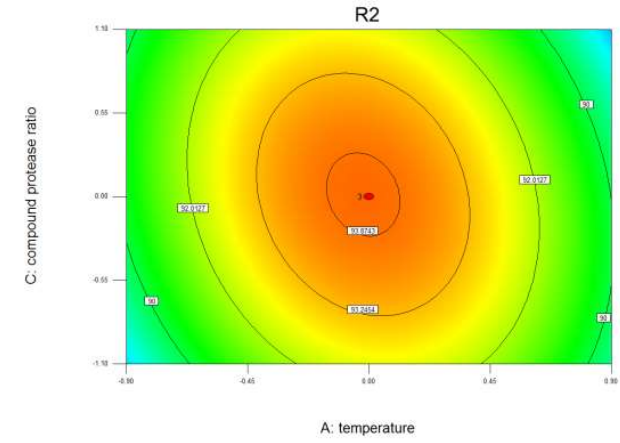

(e)

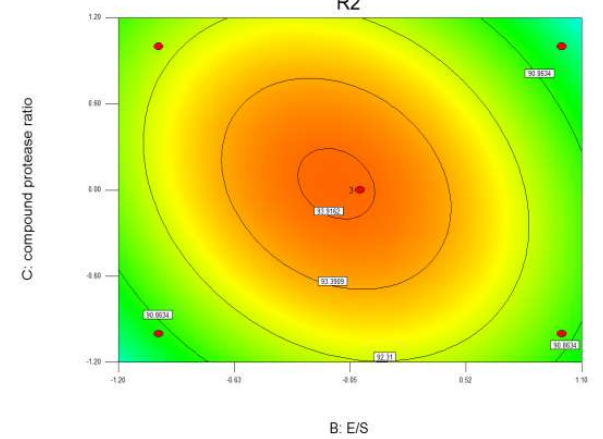

(b)

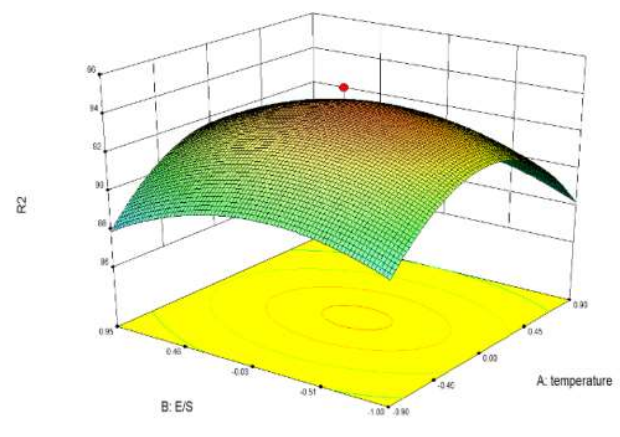

(d)

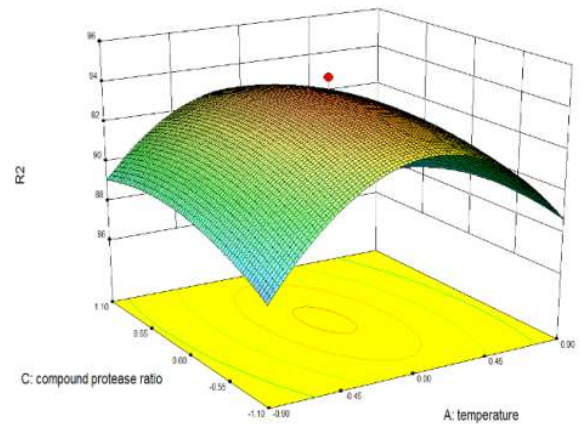

(f)

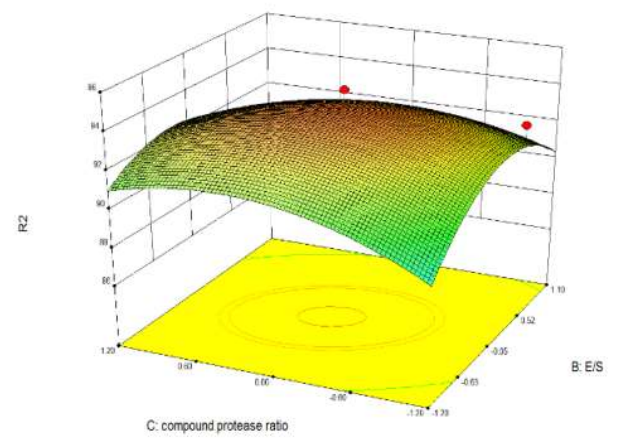

Figure 2. Response surface (right) and contour (left) plots of A (temperature), B (E/S), C (compound protease ratio) and its mutual interaction to $\mathrm{R} 2\left(\mathrm{Fe}^{2+}\right.$ chelating ability) 
Table 5. The ANOVA of Box-Behnken of superoxide radical scavenging activity in the enzymatic hydrolysates

\begin{tabular}{ccccccc}
\hline Source & SS & DF & MS & F & Pr $>$ F & Significance \\
\hline Model & 139.57 & 9 & 15.51 & 17.71 & 0.0028 & $* *$ \\
A & 10.49 & 1 & 10.49 & 11.98 & 0.0248 & $*$ \\
B & 0.00361 & 1 & 0.00361 & 0.00347 & 0.9553 & \\
C & 0.42 & 1 & 0.42 & 0.48 & 0.5542 & \\
AB & 8.04 & 1 & 8.04 & 9.18 & 0.0391 & $*$ \\
AC & 0.44 & 1 & 0.44 & 0.51 & 0.5436 & $*$ \\
BC & 9.00 & 1 & 9.00 & 10.28 & 0.0323 & $*$ \\
$\mathrm{~A}^{2}$ & 29.71 & 1 & 29.71 & 33.93 & 0.0055 & $*$ \\
$\mathrm{~B}^{2}$ & 79.29 & 1 & 79.29 & 90.57 & 0.0005 & $*$ \\
$\mathrm{C}^{2}$ & 16.12 & 1 & 16.12 & 18.41 & 0.0226 & \\
Residual & 4.38 & 5 & 0.88 & & & \\
Lack of fit & 3.87 & 3 & 1.29 & 5.12 & 0.3595 & \\
Pure error & 0.50 & 2 & 0.25 & & & \\
Cor Total & 143.94 & 14 & & & & \\
\hline$* * * p<0.001$, extremely significant $* * * p<0.01$, very significant; $*<<0.05$, significant. &
\end{tabular}

When the temperature was $61^{\circ} \mathrm{C}, \mathrm{E} / \mathrm{S}$ was $5.60 \%$, and protease ratio was $1.8: 1$, the maximum responses values of DPPH radical scavenging activity was $75.53 \%, \mathrm{Fe}^{2+}$ chelating ability was $93.90 \%$, and superoxide radical scavenging activity was $51.89 \%$. The verification experiment was performed based on the optimal conditions given by Design-Expert, and the results showed that DPPH radical scavenging activity, $\mathrm{Fe}^{2+}$ chelating ability, the superoxide radical scavenging activity were $74.81 \pm 0.93 \%, 93.44 \pm 1.46 \%$ and $51.69 \pm 1.17 \%$, respectively. The error between the predicted value and the verification value was small, which indicated that the predicted optimal condition was relatively reliable.

Before optimization of the conditions of hydrolysis, when the temperature was $55^{\circ} \mathrm{C}$, E/S was $1 \%$, and compound protease ratio was $1: 1$ the DPPH radical scavenging activity, $\mathrm{Fe}^{2+}$ chelating activity and superoxide radical scavenging activity were $63.69 \%, 90.84 \%$ and $45.06 \%$ respectively (Shu \& Mei, 2018) (data not shown). Therefore, after the optimization, the DPPH radical scavenging activity, $\mathrm{Fe}^{2+}$ chelating activity and superoxide radical scavenging activity were improved with $11.84 \%, 3.06 \%$ and $6.83 \%$ respectively.

In the previous study (Shu \& Mei, 2018) the temperature, E/S ratio and protease ratio were selected as the main factors to influence the antioxidant activity of the goat milk casein hydrolysates. The temperature of enzymatic hydrolysis is an important factor affecting the molecular stability of protease (Kuehler \& Stine, 2010). 
(a)

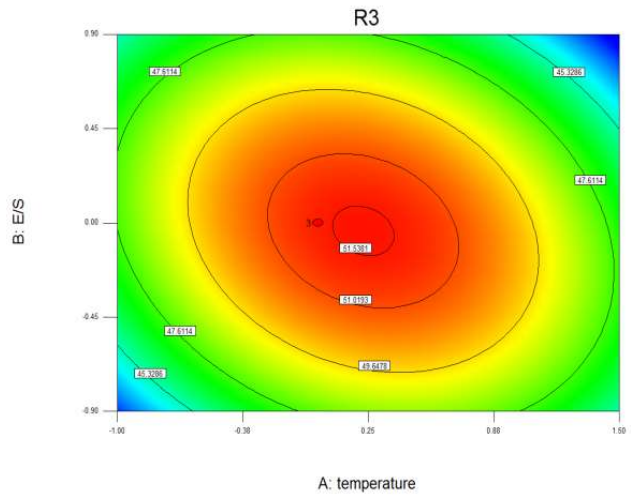

(c)

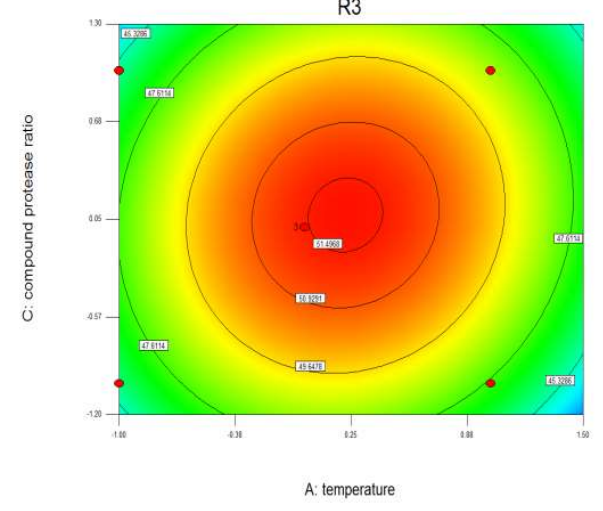

(e)

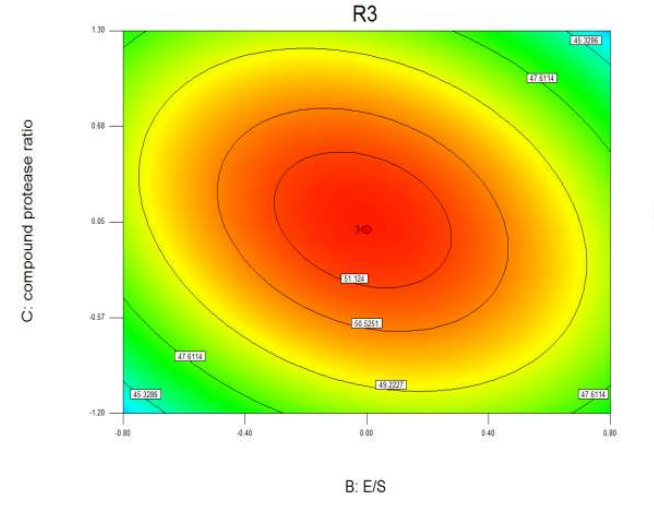

(b)

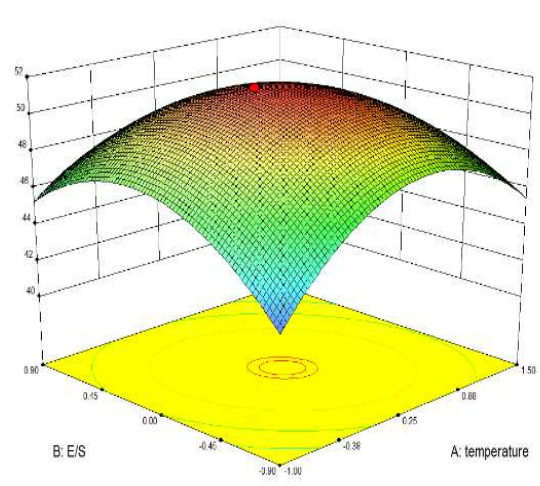

(d)

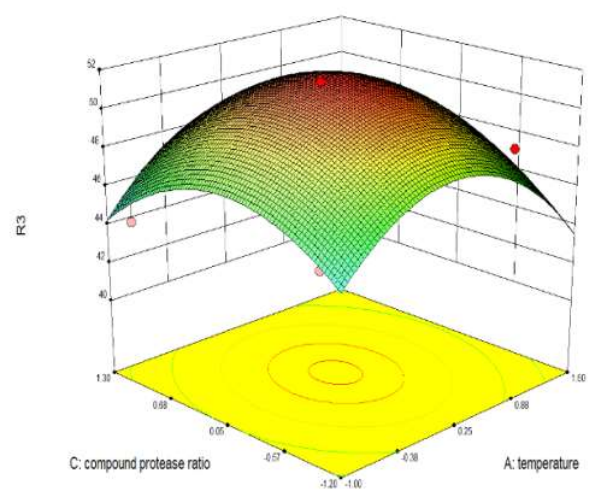

(f)

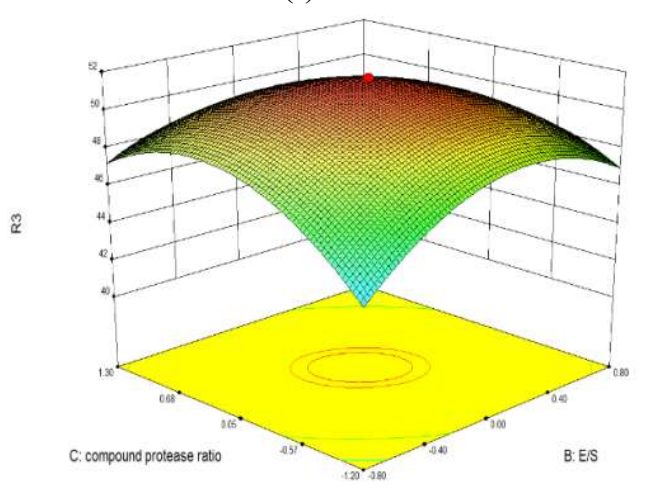

Figure 3. Response surface (right) and contour (left) plots of A (temperature), B (E/S), C (protease ratio) and its mutual interaction to $\mathrm{R} 3$ (superoxide radical scavenging activity) 
When the temperature of the enzymatic hydrolysis is high, it is easy to cause dissociation of the secondary bond and lead to the protease partially or completely inactivated. However, when the temperature of enzymatic hydrolysis is low, the rate of action between proteases and substrates is decreased because the degree of molecular motion in the system is slow. Kumar et al. (2016) reported that camel milk proteins were hydrolyzed by alcalase, $\alpha$-chymotrypsin and papain. Hydrolysis was carried out at $55^{\circ} \mathrm{C}$ for alcalase and papain, which was lower than $61^{\circ} \mathrm{C}$ that was studied in the present paper. The optimum hydrolysis temperature for both papain and alcalase was shown to be in the range of $55-65^{\circ} \mathrm{C}$ (Rui et al., 2012). Thus, the hydrolysis temperature of $61^{\circ} \mathrm{C}$ that was used in the present study was reliable.

Shu et al. (2016) used single factors experiment to investigate the various factors effect on antioxidant peptides hydrolyzed from goat's milk casein by alcalase. The result showed that the optimal hydrolysis condition of $\mathrm{E} / \mathrm{S}$ ratio was $2.0 \%$. However, in this study, the optimized $\mathrm{E} / \mathrm{S}$ was $5.6 \%$, most probably because the compound protease may had a better hydrolysis than one protease. Under the optimal condition of alcalase hydrolysis goat milk casein, the DPPH free radical scavenging ability was $69.07 \pm 1.26 \%, \mathrm{Fe}^{2+}$ chelating ability was $87.21 \pm 0.88 \%$, and superoxide radical scavenging activity was $49.18 \pm 1.42 \%$ (Shu et al., 2017). Instead, in the present study, DPPH free radical scavenging rate, $\mathrm{Fe}^{2+}$ chelating ability, the superoxide radical scavenging activity reached values of $73.81 \pm 0.93 \%$, $93.44 \pm 1.46 \%$ and $51.69 \pm 1.17 \%$, respectively. The results obtained in the present study also proved that the compound enzymatic hydrolysis is better than those of single enzyme (Abeyrathne et al., 2014). This is related to the specificity of enzymes, due to the different sites of each enzyme action, the peptide fragments generated are limited. However, under the action of the complex enzyme, complementary action is formed among each other, so more highly active antioxidant peptides can be obtained.

Espejo-Carpio et al. (2016) investigated the biological activity of goat milk protein hydrolysis prepared by subtilisin, trypsin and a combination of these two enzymes, and found that hydrolysis employing mixtures of subtilisin and trypsin was considered a good approach to produce biopeptides. Antioxidant and sensory properties of Nile tilapia protein hydrolysis prepared by one- and two-step hydrolysis using commercial protease were investigated by Yarnpakdee et al. (2015), and the results showed that the use of alcalase in combination with papain for hydrolysis of protein isolate rendered the hydrolysates with antioxidant properties and reduced bitterness, which could serve as a functional supplement. This result is in agreement with our study, indicating that the combination of alcalase and papain is more conducive to the production of highly active antioxidant peptide.

\section{Conclusions}

The optimal conditions for the preparation of antioxidant peptides by protease hydrolysis of the goat milk casein were optimized by RSM. According to the 
regression model, the optimal enzymatic hydrolysis condition was $61^{\circ} \mathrm{C}, 5.6 \% \mathrm{E} / \mathrm{S}$ ratio, and compound protease ratio of 1.8:1. Under the optimal conditions, DPPH radical scavenging activity, $\mathrm{Fe}^{2+}$ chelating ability and superoxide radical scavenging activity of the goat milk hydrolysates were $73.81 \pm 0.93,93.44 \pm 1.46 \%$ and $51.69 \pm 1.17 \%$ respectively. The validation values were close to the predicted value, so the optimized antioxidant peptide parameters by protease hydrolysis of the goat milk casein were feasible.

\section{Acknowledgments}

The work was partly supported by the key project of Science and Technology Department of Shaanxi Province (No. 2018ZDXM-NY-085), the science and technology project of Xi'an city [201806118YF06NC14(2)], the science and technology project of Xianyang city (No.2017K02-69) and Collaborative innovation project of Shaanxi Province (No. 2017XT-19).

\section{References}

Alashi, A.M., Blanchard, C.L., Mailer, R.J. 2014. Antioxidant properties of Australian canola meal protein hydrolysates. Food Chemistry, 146(3), 500-506.

Abeyrathne, E. D., Lee, H. Y., Jo, C. 2014.Enzymatic hydrolysis of ovalbumin and the functional properties of the hydrolysates. Poultry Science, 93(10), 2678-86.

Boboev, A., Hasanov, A., Yotova, L. 2012. Antioxidant activity of peptides obtained from wheat and cottonseed proteins. Bulgarian Journal of Agricultural Science, 18(1), 103111.

Chilliard, Y., Glasser, F., Ferlay, A. 2010. Diet, rumen biohydrogenation and nutritional quality of cow and goat milk fat. European Journal of Lipid Science and Technology, 109(8), 828-855.

Decker, E.A., Welch, B. 1990. Role of ferritin as a lipid oxidation catalyst in muscle food. Journal of Agricultural and Food Chemistry, 38(3), 674-677.

Espejo-Carpio, F.J., García-Moreno, P.J., Pérez-Gálvez, R. 2016. Effect of digestive enzymes on the bioactive properties of goat milk protein hydrolysates. International Dairy Journal, 54, 21-28.

Freitas, A.C., Andrade, J.C., Silva, F.M. 2013. Antioxidative peptides: trends and perspectives for future research. Current Medicinal Chemistry, 20(36), 4575-94.

Galadari, S., Rahman, A., Pallichankandy, S. 2017. Reactive oxygen species and cancer paradox: To promote or to suppress? Free Radical Biology and Medicine 104,144-164.

Ionescu, A., Aprodu, I., Daraba, A., Porneala, L. 2008. The effect of transglutaminase on the functional properties of the myofibrillar protein concentrate obtained from beef heart. Meat Science, 79 (2), 278-285.

Jomova, K., Valko, M. 2011. Importance of iron chelation in free radical-induced oxidative stress and human disease. Current Pharmaceutical Design, 17, 3460-73.

Ko, S.C., Kim, D., Jeon, Y.J. 2012. Protective effect of a novel antioxidative peptide purified from a marine Chlorella ellipsoidea, protein against free radical-induced oxidative stress. Food and Chemical Toxicology, 50(7), 2294-2302. 
Kapadiya, D.B., Prajapati, D.B., Jain, A.K. 2016. Comparison of Surti goat milk with cow and buffalo milk for gross composition, nitrogen distribution, and selected minerals content. Veterinary World, 9 (7), 710-716.

Kuehler, C.A., Stine, C.M. 2010. Effect of enzymatic hydrolysis on some functional properties of whey protein. Journal of Food Science, 39(2), 379-382.

Kumar, D., Chatli, M.K., Singh, R. 2016 Enzymatic hydrolysis of camel milk casein and its antioxidant properties. Dairy Science and Technology, 96(3), 391-404.

Li, Z., Jiang, A., Yue, T. 2013. Purification and identification of five novel antioxidant peptides from goat milk casein hydrolysates. Journal of Dairy Science, 96(7), 4242-4251.

Marklund, S., Marklund, G. 1974. Involvement of the superoxide anion radical in the autoxidation of pyrogallol and a convenient assay for superoxide dismutase. Febs Journal, 47(3), 469-474.

Najafian, L., Babji, A.S. 2014. Production of bioactive peptides using enzymatic hydrolysis and identification antioxidative peptides from patin (Pangasius sutchi) sarcoplasmic protein hydolysate. Journal of Functional Foods, 9(1), 280-289.

Nagai, T., Inoue, R., Suzuki, N. 2006. Antioxidant properties of enzymatic hydrolysates from royal jelly. Journal of Medicinal Food, 9(3), 363- 367.

Pham-Huy, L.A., He, H., Pham-Huy, C. 2008. Free radicals, antioxidants in disease and health. International Journal of Biomedical Science, 4(2), 89-96.

Ray, P.D., Huang, B.W., Tsuji, Y. 2012. Reactive oxygen species (ROS) homeostasis and redox regulation in cellular signaling. Cellular Signalling, 24(5), 981-990.

Rui, X., Boye, J.I., Simpson, B.K. 2012. Angiotensin I-converting enzyme inhibitory properties of Phaseolus vulgaris, bean hydrolysates: Effects of different thermal and enzymatic digestion treatments. Food Research International, 49(2), 739-746.

Stlolz, P. 2003. Biological ffundamentals of yeast and lactobacili fermentation, In: Handbook of Dough Fermentations. Kulp K., Lorenz K, Macel Dekker Inc.

Sarmadi, B.H., Ismail, A. 2010. Antioxidative peptides from food proteins: a review. Peptides, 31, 1949-56.

Shu, G., Zhang, Q., Chen, H. 2015. Effect of five proteases including alcalase, flavourzyme, papain, proteinase $\mathrm{K}$ and trypsin on antioxidative sctivities of casein hydrolysate from goat milk. Acta Universitatis Cibiniensis. Series E: Food Technology 19(2), 65-74.

Shu, G., Zhang, B., Zhang, Q. 2016. Effect of temperature, pH, enzyme to substrate ratio, substrate concentration and time on the antioxidative activity of hydrolysates from goat milk casein by alcalase. Acta Universitatis Cibiniensis. Series E: Food Technology, 20(2), 29-38.

Shu, G., Wang, Z., Chen, L. 2017. Enzymolysis technology optimization for production of antioxidant peptides from goat milk casein. Acta Universitatis Cibiniensis. Series E: Food Technology, 21(1), 51-60.

Shu, G., Mei, S. 2018. Application of Plackett-Burman design in screening the main factors on antioxidative activity of goat milk casein hydrolyzed by alcalase and papain. ACTA Scientiarum Polonorum Technologia Alimentaria, 17(3), 257-266.

Wu, H.C., Chen, H.M., Shiau, C.Y. 2003. Free amino acids and peptides as related to antioxidant properties in protein hydrolysates of mackerel (Scomber austriasicus). Food Research International, 36(9), 949-957. 
Yu, H.C., Hsu, J.L., Chang, C.I. 2017. Antioxidant properties of porcine liver proteins hydrolysed using Monascus purpureus. Food Science and Biotechnology, 26(5), $1217-$ 1225.

Yarnpakdee, S., Benjakul, S., Kristinsson, H.G. 2015. Antioxidant and sensory properties of protein hydrolysate derived from Nile tilapia (Oreochromis niloticus) by one- and two-step hydrolysis. Journal of Food Science and Technology, 52(6), 3336-3349. 